\title{
Biafra, Humanitarian Intervention and History
}

\author{
Marie-Luce Desgrandchamps \\ Author of L'Humanitaire en guerre civile: La crise du Biafra (1967-1970) (2018) \\ Lasse Heerten
}

Author of The Biafran War and Postcolonial Humanitarianism: Spectacles of Suffering (2017)

Arua Oko Omaka

Author of The Biafran Humanitarian Crisis, 1967-1970, International Human Rights and Joint Church Aid (2016)

Kevin O'Sullivan

Author of Ireland, Africa and the End of Empire: Small State Identity in the Cold War, 1955-75 (2012)

Bertrand Taithe

Historian of humanitarianism and director of the Humanitarian and Conflict Response Institute

\begin{abstract}
This roundtable took place on 16 January 2020, at the occasion of the fiftieth anniversary of the end of the war in Biafra. It brought together Marie-Luce Desgrandchamps, Lasse Heerten, Arua Oko Omaka and Kevin O'Sullivan. The roundtable was organised and chaired by Bertrand Taithe, University of Manchester.
\end{abstract}

Keywords: Biafra, Nigeria, genocide, history

Bertrand: I would like to start with a very simple question: why should we care about the history of the Biafran conflict today?

Lasse: What I have tried to understand in my work is how the Nigerian civil war became a global issue. Initially of very marginal international interest, the conflict from around summer 1968 on was perceived as the epitome of humanitarian crisis. I wanted to understand how it has become this 'Biafra', how the conflict has become the object of global humanitarian concern, a global media and protest event. One of the many things that is interesting in a case like Biafra is that it allows us to study the ways humanitarianism depoliticises conflicts. However, at the same time, I think it is important to contextualise such humanitarian campaigns and representations within the different relevant political contexts that helped generate such an event; that is what I have tried to do with the Biafran war.

Bertrand: Arua, why does the Biafran war matter from a Nigerian perspective?
Arua: Yes, that's a very interesting question. Yesterday was 15 January 2020 and exactly 50 years since the war ended officially. It means a lot because, from the Nigerian perspective, the war appears not to have ended. You are aware that the agitation for the independence of Biafra is still going on in Nigeria and, in fact, has taken a drastically global dimension now because different activist groups across the globe are advocating it. They are responding to what they feel is happening in Nigeria today, and recent events are making Nigerians remember why they went to war. When you look at the current situation in Nigeria, you discover that it's chaotic. Some of the issues that led to the war are yet to be resolved. In addition to the failure of the political class to provide effective leadership, some sections of the Federation still feel marginalised in the distribution of political goods. On an anniversary date like 15 January, you remember that Nigeria went to war and the reasons they went to war.

However, different people have different ways of looking at the Biafra war. I know that Biafra opens a 
window to other issues, particularly the international humanitarian aid. The war contributed a lot to the practice of international humanitarianism. In the course of the discussion, I will talk a little more about my work and how the history of the Biafra war still affects Nigeria and the world.

Bertrand: Can I just pick up a little bit on this Arua, because your work is very good at pointing out what Biafra or Biafran meant. In particular, you point out that within Biafra there was not a simple monolithic Igbo regime and that there were minority ethnic groups involved. So when one talks of a revival of Biafran autonomist politics today, does it strictly map on the region? Is it inclusive of those minorities or is it attached to one ethnic group in particular?

Arua: The Biafran secession movement has never been an ethnic struggle. The reason is simple. The massacres that occurred in May, July and September 1966 affected all the ethnic groups that made up Eastern Nigeria. In the current movement, you still have groups from outside Igboland who are involved in the agitation for Biafra. The reason is that the political equation in Nigeria today appears to be lopsided. If you look at the distribution of power, you discover that some ethnic groups or geopolitical zones are deliberately schemed out or not considered relevant to be accommodated. Ethnicity and religion to a large extent determine who gets what in the country's political configuration. The question of ethnicity becomes more prominent when you are dealing with issues concerning the security of the country. As it stands now, most of the security chiefs come from a particular part of the country - the North, and then a particular section of the country - the South East - is not considered at all. Yet, Nigeria supposedly has what is called the Federal Character Commission that is intended to ensure that every state or geopolitical zone in the country is fairly represented. The whole idea of the Federal Character Commission is to give a sense of belonging to every group and ensure that no section is dominated, but that is not the situation in the current political dispensation.

In Nigeria today, the idea of inclusivity is hardly considered an important factor in sustaining national unity. Some ethnic groups appear to be treated as political outcasts. They feel they are politically excluded or marginalised by the leadership of the county, and that creates a sense of alienation among such groups. When some people feel they're not being carried along, their loyalty and sense of commitment to national unity become weak. The people of Southeastern Nigeria [Igbos], who fought hard for the Biafran secession, strongly believe they are still being punished because of the secession. The South-South zone, where much of the oil is produced, is also suffering the same marginalisation in political appointments. So when you talk about the Biafran struggle you find some people in Rivers State [South-South zone] who strongly believe in Biafra because they're not given that sense of belonging in the distribution of power and resources. This is why there appears to be a common view that Nigeria is not united.

Bertrand: Kevin, can you tell us where Biafra matters from your perspective?

Kevin: When I first came to work on Biafra, it was because of the impact it had on Ireland and, in particular, how a crisis of that nature transformed the way that Irish people encountered the Third World [Bateman, 2012; O'Sullivan, 2012; Staunton, 1999]. From there I became very interested in the popular response to the crisis in the West and its long-term impact on the humanitarian sector. There are two strands to this story. The first is the enduring image the conflict and the humanitarian response established of what the Third World was and what Western intervention could - and should - look like [Cronje, 1972; de St. Jorre, 1972; Gould, 2013; Moses and Heerten, 2018; Omaka, 2016]. The second strand to this narrative is that Biafra was a significant moment for the creation of the modern non-governmental organisation system. The period from around the late 1960 s to the mid 1980s - from Biafra to Live Aid, if you like - brought about a transformation in scale and purpose of non-governmental aid. To put this in very simple terms, the number of NGOs increased considerably around the turn of the 1960s and the early 1970s, the funding landscape changed dramatically and the public perception of NGOs was also altered irrevocably [Chabbott, 1999: 227; Hilton et al., 2012: 301]. Biafra might not have been the first instance of popular support for NGOs, but it certainly accelerated their development into the kind of sector that we are familiar with now [O'Sullivan et al., 2016].

Marie-Luce: I agree with what Kevin has just said. Biafra is a very interesting moment from which to observe the reconfigurations taking place within the international aid system at the end of the 1960s. It also showed how NGOs and other humanitarian organisations became central actors of the North-South relations.

Bertrand: One issue I would like us to discuss relates to Biafra and debates around genocide. The Biafran war was probably the first opportunity for a sustained discussion of genocide in the 1960s and early 1970s. Secondly, to discuss the development of NGOs. So, since you've raised the issue of NGOs and you've all worked from different sources, let us discuss the range and types of non-governmental organisations you have all worked on and the kind of records and sources you have used to engage with the history of their humanitarian work.

Arua: Well, I used the UK's National Archives at Kew, Nigerian National Archives, Enugu, Canadian Archives 
[Library and Archives Canada/Bibliothèque et Archives Canada] and then some documents from the United States' National Archives and Records Administration. I also conducted oral interviews in Nigeria and Canada. In fact, my fieldwork was an opportunity to meet some people who were directly involved in the relief work in Biafra. I interviewed some of the humanitarian workers from Canada and that helped a lot in my research. I also interviewed people in Nigeria. I worked on the Joint Church Aid, a consortium of Catholic and Protestant churches. It was formed during the war, and the founders were primarily moved by the catastrophe in Biafra. They intervened on humanitarian grounds and their job was to provide relief aid to the blockaded people of Biafra, who were dying in thousands. There's something I find very interesting about the Joint Church Aid. When you look at the Joint Church Aid and its role in Biafra, you also remember the International Committee of the Red Cross [ICRC], because both of them were providing relief aid to the people of Biafra at the same time. But comparing the two groups shows us that the Red Cross had issues in providing relief aid. It was tied up in a red tape and political concerns. So it was difficult for them to take decisions. In fact, the Nigerian government accused both the Red Cross and the Joint Church Aid of interfering in their internal affairs and sustaining the Biafran struggle through relief aid. Owing to the politics of international humanitarian intervention, the ICRC suspended its nightly relief supply to Biafra, but the Joint Church Aid ignored political considerations and continued with its humanitarian aid based on moral grounds. There's something I find very interesting about the Joint Church Aid in their work in Biafra and that is what I think people who are engaged in humanitarian aid now should look into. The idea that international humanitarian aid in local conflicts produces long-term dependency.

In Biafra, I have mentioned in my book [Omaka, 2016], there was no such thing as long-term dependency. When the war ended and relief work stopped, Biafrans were able to adjust and move on with their normal life within a short time. The reason was that the Joint Church Aid encouraged the locals to engage in agricultural production. The JCA provided some farm inputs, including seeds and tools that helped the people who were not in war zones. During much of the war period, the people of Biafra engaged in farming to support the relief aid. When the war ended, famine did not end immediately, but the people still survived. So I find it very interesting that that initiative of encouraging local support, which I am not sure is common these days, helped to check the tendency of experiencing long-term dependency. Prolonged dependency exists now probably different dimension and is now run more like a business with a huge budget.

Bertrand: Again we're talking about what we would now call 'faith-based organisations' - and I wonder, Kevin, if you could say what is the specificity of this kind of religious presence in the response to Biafra?

Kevin: Nigeria was a land of missions in the 1960s. For example, when the war broke out, there were over seven hundred Irish Catholic nuns, priests and brothers in the Eastern Region [Missionary Service Centre, 1968]. Although that number dwindled after many of them were evacuated, those who remained had a considerable impact both on the logistics of the crisis and how it was understood in the West. Catholic and Protestant missionary networks provided a robust logistical framework for the delivery of aid. Food and medical supplies that arrived via the faith-based Joint Church Aid airlift - beginning in spring 1968 and running until Biafra's collapse in January 1970 - were distributed to local communities through these networks [Byrne, 1997; Daly and Saville, 1971; Omaka, 2016]. The missionaries' presence in Biafra also had the effect - to borrow a phrase that Lasse has used in his work - in bringing the crisis 'close' to people in the West. In Canada and Ireland, for example, the Christian churches played a very prominent role in making the crisis intelligible to the public - by providing a direct connection to West Africa. In the Irish case, that was very visible in how missionaries from the Holy Ghost Order dominated the media narrative. They created connections to local communities in Ireland by naming individual missionaries and describing their role in delivering relief, by putting them up for media interviews and by maintaining their prominence in how the crisis was reported. Holy Ghost missionaries were also very involved in the establishment of Africa Concern [now Concern Worldwide] in March 1968 [Farmar, 2002]. Canadian engagement with the crisis was reliant on similar, faith-based connections. The links that Presbyterians, for example, had established in the East in the 1950s - including, importantly, with some of the Biafran leadership - were significant in the birth of Canairelief in late 1968 [Bangarth, 2016]. The major British NGOs - particularly Oxfam and Save the Children - also worked alongside, and provided funding for projects run by missionaries.

Lasse: To follow up on that, what I think is particularly interesting about the missionaries, beyond what Kevin has already summarised, is that they helped create this global event 'Biafra', and helped shape the way Biafra was read by many contemporaries. They did so in a way that resonated forcefully within religious circles - but this framing also increasingly transcended religion. What many missionaries and others in church organisations were initially concerned about was driven by an 
understanding of the war along the lines of a religious conflict. But that was not something that necessarily inspired many contemporaries beyond Christian circles. As a result, they also started activating networks that went beyond the churches. To provide one example, in early summer 1968, a group of the Irish Holy Ghost Fathers stationed in Biafra toured the United States to create new networks of support for Biafra. During this tour, they met with the leadership of the American Jewish Committee in New York. In the meeting, they spread out photographs of famished Biafran children, prompting reminders of the Holocaust. The sources show us that the Holy Ghost Fathers already verbally framed the pictures in that way themselves. Feeling reminded of reports by survivors of the camps in the 1940s, the American Jewish leaders felt they could not make the mistake of ignoring them again: they had to do something about this crisis that was feared to be a potential new genocide. For these American Jewish organisations, it was the first non-Jewish issue for which they engaged themselves [Heerten, 2015, 2017: 175204]. The missionaries thus were a key transmitter of the crisis. In effect, significant echo chambers of this crisis were found within Christian circles, Catholics and also many Protestants. However, at the same time, the missionaries framed the conflict in a way that went beyond religion as an issue, and they thus played a big role in turning this political conflict into a humanitarian issue [Heerten, 2017: 83-104].

Marie-Luce: They were also key players in bringing and touring journalists in Biafra. We often remember the work of the public relations agency, Markpress, hired by the Biafra government in that respect, but the Holy Ghost Fathers and the missionaries in general acted very much as 'mediators' in the field between the journalists and the situation in Biafra. Compared with other humanitarian organisations, their knowledge of the ground and their presence within the population for years made a real difference and explained the rapidity and effectiveness of their mobilisation.

Bertrand: I think today when we teach the history of the Biafran War, the students are always struck by, on the one hand, the extreme modernity of the Biafran conflict, but also, on the other, by how distant it is from their current practice. One aspect that always strikes them is of course, the use of what we might want to call - crudely propaganda and communication strategies. This is the view that this is a war that became internationalised largely because of networks that reached far and deep into the West and which had a religious undertone. But we also know that there is a very strong revival of the framing of the violence, of the conflict and of the famine and in the terms of a genocide. So if we think about how this happened, I wonder, Arua, if you could tell us how this communication of the Biafran conflict arose from a Nigerian perspective, please?

Arua: Yes, I think I should actually start by saying that Biafrans had a good understanding about marketing of the war and connecting with the international community. Initially, they were managing it locally, but at some point they discovered that it was very necessary to reach out to the international community. The need for international involvement became more pressing when it became obvious that the blockade imposed by the Nigerian government was having a serious effect. Children and nursing mothers, who were the major victims of the war, were dying in thousands daily due to kwashiorkor (acute protein deficiency) and marasmus. So the people of Biafra had to engage Markpress, a Geneva-based public relations firm to sell their war aims to the global community. Markpress did a very good job by bringing in some journalists who witnessed the war in Biafra and then reported to the global community. It had a good distribution network that worked very well. But there is something that people didn't know about the role of Markpress. Many observers in Europe and North America thought that Markpress generated the information it transmitted to Europe and North America. This is not true. Markpress primarily depended on information transmitted by Biafrans. In other words, Markpress largely distributed the information provided by the Biafran propaganda directorate.

Biafra had a strong propaganda machine that coordinated the war communications locally and internationally. The propaganda directorate based in Biafra was able to sustain the support of the people of Biafra till the war ended. Leaders of the Biafran government often told Biafrans the efforts they were making locally and internationally. They also told them who was responsible for the bomb attacks on civilian targets and their suffering. For example, it was usually appealing for Biafrans to hear that they were fighting with Britain and not Nigeria. They saw the British Prime Minister, Harold Wilson, as the real enemy of Biafrans while General Gowon [military head of the Nigerian state] was portrayed as his deputy. The USSR also gave open support to the Nigerian government. What helped Biafra so much was the kind of propaganda machine it was able to set up. The Biafran propaganda directorate was made up of well-educated people, some of whom were trained in some of the best universities in Europe and North America. They returned to Nigeria primarily to support the Biafran war efforts and had to put in their best.

Bertrand: Lasse, do you want to pick up on these issues about who were the real channels or the amplifiers of what you called the echo chamber?

Lasse: From very early on in the conflict, the Biafrans tried to open up a new front on the international stage 
with their PR machine. However, in the beginning, their publicity did not really catch on; the international public were barely interested in the Nigerian civil war. If we want to understand what turned the conflict into something that contemporaries were concerned and cared about, then the moment that the images of the starving Biafran children were published was key. We often think of images as standing for themselves, speaking for themselves. I do not think that is true. I think we need very powerful external references to turn images into what some art historians have called an 'image act' [Bredekamp, 2015]. Two things were vital: first, the Holocaust images - the Holocaust comparisons [Heerten, 2015), and second was the place of Biafra within what historians now often call the 'global 1960s' and the protests of the period. I can expand on both dimensions, but for now, I would like to start with the Holocaust comparisons.

This rhetoric and the visual connections were of vital importance. Right from the start, when these images began arriving in Western publics, published in mass media outlets, they were read with references to what we - at least now - call the Holocaust. In the period, something that may be dubbed 'Holocaust memory' was beginning to form. Already then, the images of the liberation of the camps from 1945, taken by soldiers or photographers that accompanied allied troops to camps like Bergen-Belsen, were present in the publics. These images already had been very present in Western publics from the final stages of the war, then widely disappeared from public sight for a while, but had returned in the 1960s - a few years before Biafra [Brink, 1998; Knoch, 2001; Sliwinski, 2011: chapter 4; Zelizer, 1998].

Bertrand: Historians of the Holocaust are always keen to point out that, though the Holocaust was never silenced [Cesarani and Sundquist, 2011] and that the Eichmann trial in 1961 brought it in sharper focus, much of the public awareness took place almost after Biafra rather than before. So could you clarify whether the Biafran conflicts actually did not only rely on stock imagery, but also fuelled a new awareness of the meaning of genocide and of the Holocaust?

Lasse: Yes, exactly. At first sight, this argument seems circular, but I think that was the dynamic: Biafra was turned into a legible event through references to the Holocaust, but also vice versa. The Holocaust was also increasingly understood as genocidal through references to Biafra. From summer 1968 - at least until October 1968, when the reports of the Observer Team Mission invited by Lagos on London's initiative to counter Biafran publicity discarded the genocide allegations for many contemporaries - Biafra was established as an international issue in that manner. Yet Biafra also helped establishing the Holocaust as a genocide, singled out from Nazi crimes more generally: genocidal in nature, targeting minority groups and primarily the Jews. These references are thus interesting and insightful not only to get a better grasp of the Nigerian civil war, but they can also help us better understand the mechanics of Holocaust memory [Heerten, 2017, 280-4; Smith, 2014; Heerten and Moses, 2014].

Moreover, these references also lead us into the global 1960s. It is only partly true that Biafra was the first postcolonial conflict that was discussed as a genocide but the way these references worked changed with Biafra. Already before the American war in South East Asia, what is usually called the Vietnam War was then described as possibly genocidal. This was something that many New Leftists at least were concerned about. Some of their leading figures and intellectuals associated with them, notably Bertrand Russell and Jean-Paul Sartre, put up the International War Crimes Tribunal in 1966. Genocide in a third world conflict had thus already been widely discussed - but mainly within a leftist counter public, and part as a dominant paradigm of anti-imperialism. Imperialism created genocides, and this was hence the main issue from this perspective (Kalter, 2016). What was new about Biafra was that international mainstream media, like The Times or Der Spiegel, started covering a postcolonial conflict and not only posed the question whether genocide was occurring: numerous reports explicitly stated that what contemporaries were not witnessing - and could also watch live on TV - was a genocide. This was something genuinely new; no contemporary conflict had been discussed in these terms in mainstream media before. This was a qualitative difference, and the connection to 'imperialism' was also severed. This is but one of many ways how placing Biafra in the global 1960s helps us understand how Biafra was established as a global issue. Biafra was not a New Leftist issue, but without looking into the world of leftist politics of the time we cannot really understand the conflict's international dimension as a humanitarian event [Heerten, 2017: 205-62].

Bertrand: Do you want to pick that up, Kevin?

Kevin: I find the reference that Lasse makes to the global 1960s very interesting. To return to a theme we discussed earlier, one of the reasons why the crisis was engaged with so widely is that it was constructed in such a way as to make it more personalised and relatable than events in Vietnam, Prague, Paris and elsewhere in that period [Smillie, 1985: 80]. It is quite striking that the genocide narrative also de-politicised the humanitarian crisis of access to food, by focusing attention on the image of the child that Lasse mentioned. In that telling, the 'saving' impulse overrode any reference to the complexity of the crisis: how could one deny aid to children who knew nothing about the politics of this 
conflict? The cleverness of the Markpress campaign was to simultaneously play on these humanitarian sympathies as a way of generating support for the Biafran cause, while also suggesting that humanitarian intervention should remain 'above' politics. This was a very deliberate process. It was only when the Biafran authorities hired Markpress in spring 1968, and only after Markpress invited foreign journalists to tour the region in April 1968, that the narrative of the crisis was transformed into what we have already discussed.

Having said that, I think it is important not to lose sight of how this universalising narrative was interpreted differently in different national contexts. One of the key lessons that Biafra holds for contemporary humanitarian campaigning lies in understanding why and how it became something that the public latched on to. To give the three examples that I'm very familiar with: in the British case, the response was wrapped up in a paternalistic feeling of postcolonial responsibility toward Nigeria and to the people there, but also an attempt to construct a new identity for Britain and to distance the popular response from criticisms of the British government for selling arms to the Federal Military Government while simultaneously pronouncing its concern for those affected by the conflict [Bocking-Welch, 2019; Smith, 2014].

In Canada, the response to Biafra is deeply entangled with the country's centenary celebrations and the concurrent attempt to develop a new 'global helpmate' identity. Canairelief, for example, became a symbol of Canadian altruism, while Biafra was 'the war that stabbed Canada's conscience' [Bangarth, 2016; Myers, 2014; Starowicz and Oliver, 1970)]. And then in Ireland, the crisis was framed very much in terms of (anti-) colonialism. Irish missionaries, in particular, liked to frame what was happening to the Biafrans as akin to what the Irish had experienced in the British Empire. The spectre of famine was particularly significant in this respect. The phrase 'The Great Hunger' - which had been popularised as the title of Cecil Woodham-Smith's hugely successful 1962 book - was used repeatedly by Irish missionaries and NGOs in relation to Biafra. Whether such common feeling ever existed is debatable, but it constructed quite a potent image of Biafra in the minds of Irish people [O'Sullivan, 2014].

Bertrand: Arua, you start your book by a description of the celebration of independence in Nigeria. So I guess that the whole question of how we locate the Biafran conflict in relation to anti-colonial and post-colonial politics in Africa is essential. So could you tell us a little bit more about that?

Arua: The issue with the Biafran struggle is that it happened at a time when African countries were just gaining independence and anti-colonial struggle was still going on. That, to a large extent, worked against the
Biafran secession. Nigeria played a significant role in the decolonisation of Africa and was believed to be a symbol of democracy in Africa. Based on the enormous human and material resources, the expectation was high. People expected that the country would move at a fast pace in terms of development. Nigeria asked for independence and it was granted. But within a space of six years, the country was engulfed with a series of conflicts that led to the collapse of the constitution and the eventual outbreak of the war.

Different people, including African leaders, made efforts to ensure that the crisis did not go out of control by bringing the Eastern Region and the Federal Government of Nigeria to the negotiating table, but those efforts failed. The Nigerian government in its propaganda argued that if Biafra succeeded, not only the rest of Nigeria but other countries in Africa would also disintegrate along ethnic lines. Although the Biafran secession was not an ethnic movement, many African leaders seemed to have believed that hypothetical consequence to other African countries. There was also this analogy that Biafra was another Katanga. The Katanga crisis had happened at the beginning of the 1960s and was almost a global event. And soon after that, Biafra emerged and most African leaders became worried about the implication of the secession on the entire continent.

You've got the argument that if Biafra succeeded in pulling away from the Federation, then it will send a signal to other groups in other African countries. But when you look at the argument critically, you find out that there was no Biafra in all the countries in Africa. The Eritreans and the Southern Sudanese were unlikely to have been strengthened in their struggle by the knowledge of the secession of Biafra. Biafra, from my own understanding, had its own peculiarity. It did not share the same experience with Katanga. When people compare Biafra with Katanga, there are some critical questions that come to mind. Did Katanga have the massacre experience that people of Eastern Nigeria had in Northern Nigeria? Did Britain support Biafra, as Belgium did in Katanga? Katanga was obviously a case of foreign intervention intended to recapture the resources in the whole of the Democratic Republic of Congo. It was not a genuine secession. So the idea that Biafra was another Katanga was one of those propaganda tools the Nigerian government and the British designed to run down the image of Biafra. Therefore, the Katanga analogy and the domino theory were baseless. Different countries in African had their postcolonial issues to deal with. For instance, Sudan had an ongoing conflict at the time the Nigeria-Biafra war was going on. I think the reason people didn't know about the crisis in Sudan was because the country was not as richly endowed in 
mineral oil as Nigeria. Nigeria naturally drew that attention, apart from the humanitarian crisis. There was no such thing as asking what was going on in Sudan. Nobody cared about Sudan. Another side of the story is that most African leaders wanted to manage whatever was designed by the colonial authorities whether it was good or not. Hence, few African leaders supported Biafra.

Lasse: When I first looked into Arua's book I was struck by how he opens it, as it seems he had a very similar idea as myself; he opens his book basically the same way I open my first chapter. A while back, when I started writing the chapter - and indeed the book - I read contemporary reports about the independence celebrations and thought that starting with them would be a good way to open this part of the narrative in a way that conveys the friction between independence and what was happening in postcolonial Nigeria a few years into the postcolonial period [Heerten, 2017: 25-8]. Fred Cooper conceptualised this as an intertwined process of perspectives opening up and closing down in the decolonisation era; he called this process 'possibility and constraint' [Cooper, 2008]. This dynamic is also helpful to contextualise the Biafran case. The Biafran vision was spurred by a rhetoric that was resonant of the political campaigns of decolonisation, it was animated by the vision of an independent state, of nationalism and the right to self-determination as a human right. As a political campaign and in its rhetoric, Biafra was in many respects a revenant of many decolonisation projects.

However, global order had of course changed, the political forums in which the Biafrans tried to formulate these claims have changed. Many of these forums were unavailable for the Biafrans, perceived not as a selfdetermination campaign, but as a secessionist threat: the opponent that was accepted as a sovereign nation-state in intergovernmental organisations was Nigeria. This was the OAU [Organisation of African Unity] stance that determined the position of the $\mathrm{UN}$ and the wider diplomatic world, in which Biafra's campaign could not thrive, even though the rhetoric of the campaign itself was so similar to decolonisation campaigns that have been successful in the same era [Heerten, 2017: 51-82]. Biafra was a moment that showed how the right to selfdetermination was limited to one self-determination per colonial unit. It thus did not apply to the Biafran case.

Bertrand: I think Marie-Luce is very glad to hear you, Arua, talking about Katanga. As Marie-Luce has shown, we can consider the Biafran conflict in relation to the Congo independence conflicts. In Congo, a few years earlier the United Nations and the international community' had been involved and had significantly failed to stop the conflict. I think that there is a sort of a reactive dimension which has been evoked later on in international interventions in Africa in relation to Somalia and Rwanda, for example. Namely that once the international community fails in one part of Africa, it tends to neglect the next conflict usually with disastrous consequences. Do you think there's an element of that?

Marie-Luce: During the conflict, the Nigerian government was very anxious to avoid any UN involvement, and the UN did not take initiatives to mediate or intervene. And I think this is clearly linked with the difficulties faced by the UN during the Congo crisis as nobody wanted them to mingle in another secessionist crisis where postcolonial interests were at stake. Actually, this had strong consequences on the humanitarian operations, as the UN absence let space for the involvement of the non-governmental actors. For example, at the end of 1967, as they could not intervene directly, Unicef played a major role in prompting the ICRC to undertake relief activities. In other words, the trauma arising from the international community's management of the Congo crisis participated in creating the conditions for what happened in Biafra. When the famine appeared on TV screens and the pressure in the public mounted, the UN and governments provided resources (financial, material or diplomatic) to the Red Cross and the Churches. This allowed them to satisfy the public demand without getting too involved.

Kevin: I think that it is useful to think about the Biafran conflict as playing out at the junction of three overlapping trends in post-Second World War international politics. The first is the question of sovereignty. The UNHCR's refusal to intervene in Biafra is a very good example of how strictly the United Nations sometimes defined the principle of non-interference in domestic affairs - and it was echoed by the noninterventionist stance adopted by the Organisation of African Unity [Barnett, 2011: 138-42; Loescher, 2001: 146-7]. The second dynamic is geopolitical. British, Soviet and Israeli interests in the region, and the material and diplomatic support that accompanied them, were important in how the conflict was conducted [Levey, 2014; Smith, 2014]. Likewise, French, Portuguese and South Africa interference in the conflict was undertaken with the goal of destabilising Nigeria and weakening its influence in West Africa [Omaka, 2019; Siebert, 2018]. The third element of this story is the on-going transition from empire to the postcolonial era. That change manifested itself in different ways. The Africanisation of the Nigerian Catholic Church, for example, changed the role that expatriate missionaries played in the country. This had a direct impact on the humanitarian crisis in that from the mid-1960s many of the missionaries who were later involved in delivering relief began to be retrained as social workers or took 
courses in development studies - in effect, moving sideways into fields that were related to what they had done before (in the provision of education and medical assistance, for example), but adapting it to the postindependence context. We can read the visible presence of former colonial officials in the Biafran aid efforts as part of the same narrative: transitioning from roles played in empire to the world of development and the emergency aid. The continuities that Véronique Dimier has mapped in her study of EU development personnel are echoed among British NGOs [Dimier, 2014]. Save the Children, in particular, relied on colonial knowledge, but Oxfam and others also drew on similar forms of expertise from individuals who had long experience of working in Nigeria, or from those who operated in other colonial contexts and transferred to the aid sector.

Thinking about the crisis in this way is important because it allows us to understand Biafra both as something new, but also as a continuation of the language and practices used to describe humanitarian intervention in the past. The paternalism that characterised earlier interventions did not just disappear with political decolonisation, for example. While I agree that the Congo crisis was significant to the humanitarian sector's development, the currents that converged in Biafra made it more significant in shaping the aid industry that emerged in the 1970s.

Marie-Luce: Just to add something to that: we can observe these colonial legacies even in organisations such as the ICRC - that were not especially associated with former empires but that were still seeing their mission on the African continent in civilising terms as much as in humanitarian terms. The reaction of the Nigerian government, which regained control over most of the humanitarian operations in June 1969, illustrated already the potential tensions that such attitudes could create in a postcolonial world.

Bertrand: I'd like to carry on a little bit on the issue of Biafra as a partially mythologised starting point for contemporary humanitarianism. I've just wondered if you could reflect briefly on that issue: To what extent was Biafra a reconfiguration of humanitarianism and to what extent has this been mythologised?

Kevin: Building on what I said earlier, I think it is useful to see the history of humanitarianism in terms of moments of acceleration when the sector refreshes itself while also carrying with it the baggage of what came before (O'Sullivan et al., 2016). The mid-nineteenthcentury creation of the Red Cross is one such moment; so too is the aftermath of the First World War, the period following the Second World War, and later, the postCold War 1990s. Biafra has certainly been mythologised by the humanitarian community. In the case of MSF [Medécins Sans Frontières], for example, it has been constructed in such a way as to reinforce a particular image of that organisation's origins. Nonetheless, some of Biafra's tropes are actually very useful for signalling its importance. The idea that this was the first 'televised famine' is often-repeated, but it is also true. This is returning to something I mentioned earlier, but for me, Biafra was a moment of radical change - in terms of the size, the scope and visibility of the sector - but it still carried the baggage of paternalism and what Michael Barnett called 'neo-humanitarianism' into that new era [Barnett, 2011]. The book that I am currently writing makes this very argument, by following Biafra's legacy to the crisis that created independent Bangladesh (197072), through the sector's intervention in Cambodia, El Salvador and elsewhere, its expansion into development and social justice issues, and, finally, the popular fundraising extravaganza of Live Aid in the mid-1980s.

Lasse: Placing Biafra in the longue durée of colonial history is indeed significant. There was a colonial baggage of humanitarianism, echoes of colonial optic and colonial iconography; colonialism continued into the postcolonial history of humanitarianism in many ways. At the same time, Biafra is also often connected to later developments as the mythological origin of a new humanitarianism. That is something that we need to reflect on substantively, because these 'mythologisations' of Biafra have often, I am afraid, led researchers into directions that are interesting but are not necessarily helpful to understand what Biafra was about at the time. If we look at the French case more particularly, for instance, the forerunners of MSF around Bernard Kouchner were not as important a group at the time. The origins of MSF only appear in hindsight in their foundation narrative. To historicise the campaign on behalf of Biafra in France the connection to Gaullism is, I think, much more relevant, in particular until early 1969 when de Gaulle was still President. Public reactions in France were intertwined with the governmental reaction: there was substantial public and governmental support for Biafra. France never officially recognised Biafra as an independent state. But pro-Biafran public opinion and governmental support - arms deliveries and other forms of support partly channelled through and possibly prompted by initiatives from formerly French postcolonies that might have driven Paris into supporting Biafra - were directly intertwined. At the time, Biafra was crucial for a process in which a global French mission closely associated with Gaullism - was reformulated. Accordingly, we do not only need to study Biafra to help us construct genealogies of the present, the origin of something new. Many of the concepts that contemporaries used to understand the conflict were already around, such as self-determination or genocide. But the pro-Biafran campaign also established something new: 
Gaullists and disillusioned post-May leftists not interested in an anti-imperial revolution - which was the dominant way other third world conflicts, like the one in South East Asia, were understood by New Leftists established a new form of third worldism that was closely intertwined with humanitarian ideas (Davey, 2015). This new third worldism, however, was defined by audible echoes of colonial humanitarianism. It was something new, but formed by different pasts - and needs to be firmly situated within the political landscape of the global 1960s [Heerten, 2017: chapter 7].

Marie-Luce: I agree very much with both. What struck me when I started working on Biafra, especially in a francophone context, was the shortcut being made between: Biafra $\rightarrow$ creation of MSF $\rightarrow$ beginning of a new century in the history of humanitarian aid. This kind of narrative minimised all the other developments that went on during the conflict. Placing MSF founders' action in a broader context showed that their role in the general economy of the conflict was marginal: their 'témoignage' ['witnessing'] was actually part of a mediatisation campaign orchestrated by l'Elysée in France, and the ICRC was pretty happy to welcome qualified doctors into its operations. But at the same time, the creation of MSF afterwards was also part of the transformations that the conflict contributed to generating and that made humanitarian aid one of the key elements of the West-Third World relations during the following decades.

Bertrand: I'd like us to move on now. Back to you Arua. Fifty years ago, exactly, today would have been the first day after the war. So the question of course is what happened after the surrender of Biafra and what happened after this fairly massive deployment of aid, which of course took place on both sides of the conflict? Arua, can you give us a sense of the aftermath, in the days after the conflict ended?

Arua: Biafra surrendered unconditionally when the war ended and the military head of the Nigerian state General Gowon was quite magnanimous when he declared: 'No victor, no vanquished.' People originally expected a Nuremberg kind of trial but that didn't happen. There was also a kind of anxiety among international observers that there might be genocide after the war. General Gowon understood the situation, and on the advice of the British government tried to reconcile with and reintegrate former Biafrans into the Federation.

In fact, the idea of reconciliation had been central in the peace negotiation between Biafra and Nigeria even before the end of the war. People expressed concerns as to whether Biafrans would still be accepted back into the Federation as citizens with full rights. Biafrans, with the fear of genocide also wondered what their fate in the future Federation of Nigeria would be. When the war ended and there was no victor, no vanquished, everybody was happy. Then the Federal Government initiated what it called the three Rs: Reconciliation, Reconstruction and Rehabilitation. It was an impressive initiative when it was announced, so people expected that the war victims would experience quick recovery from the trauma and damages caused by the war.

But what happened after the war shows that it was just one of those political statements that were made to impress the anxious global community. So when you talk about the aftermath, you realise that Nigeria still has a long way to go. What happened immediately after the war shows that the notion of reconciliation and rehabilitation was simply a clever ruse devised by the Nigerian government to douse the tension created by the war. In fact, if you look at the way former Biafrans struggled to survive after the war, you understand that there's a form of 'genocide by silence'. Genocide does not only entail physical attack against a group. You can also deliberately keep quiet, and people in a lifethreatening situation will die as a result of silence or negligence. The way the Nigerian government responded to the needs of former Biafrans in the aftermath of the war was a not in line with the idea of reconciliation or rehabilitation.

Within a short time, however, former Biafrans were able to recover from the damages and moved on. But the situation in Nigeria today, reminds people about events that led to the war. Ineffective leadership of the country since independence has created a state of continuous tension. Nigeria doesn't look as united as it should. There's always this fear that the country might disintegrate anytime, because different ethnic groups that make up the Federation have expressed concerns about the way things are going. Anybody who has been following Nigerian politics will agree to the fact that the situation of the country, especially security, continues to get worse. The crisis of leadership in the country largely explains the resurgence of the agitation for the independence of Biafra. The issues that led to the war, especially constitutional matters are yet to be addressed. And that is the reason, today, some ethnic groups, geopolitical zones and civil society organisations talk about going back to the pre-war Federation when regions enjoyed some level of autonomy in the federation. Now you have all the power concentrated at the centre. What that means is that everybody depends solely on the Federation for sustenance and survival. Nigeria claims to operate federalism, but in fact it runs a unitary system of government. This has been part of the agitation for the review of the constitution.

Whereas some people support the idea of having a sovereign national conference to address the 
constitutional issues that threaten the unity and corporate existence of the Federation, others do not. People from southern Nigeria strongly support the agitation for the restructuring of the Federation, but the North, which seems to be benefiting from the present constitutional structure, is opposed to any form of restructuring. So it has been a contentious issue. Fifty years after independence people are still talking about whether the Federation would survive or not. In the past, people were blaming the colonial authorities for the underdevelopment of the country. How long shall we blame colonial rule? Is Nigeria not old enough to decide what it wants without blaming anybody? The country is richly endowed with human and material resources that can enable it rise to global prominence, but it lacks effective leadership and national vision. You don't see any direction in the leadership of the country; you don't see people telling you this is where we are going now. Nigeria appears to be struggling with the truth. We're not talking about development now; it's about whether the state, Nigeria, can survive or not. This is a problem and that is why people contemplate secession as a solution. And the current situation, especially the irreducible security problem makes some people think that those who wanted to break away from the Federation were right. It's a very complex problem.

Bertrand: Kevin and Lasse, could you try to give us a sense of the aftermath of Biafra for humanitarian organisations?

Kevin: The most immediate impact of Biafra's collapse was the expulsion of several relief agencies. The Joint Church Aid airlift came to an end, Concern was expelled from Nigeria, Canairelief flights ended and the organisation folded. By the end of January 1970, a sizeable number of Irish missionaries - many of whom had been prominent in the delivery of relief - were placed under arrest and eventually deported from Nigeria. In the medium term, the shift to development and rehabilitation work created opportunities for more 'acceptable' NGOs like Oxfam and Save the Children to work on Nigerian government-supervised programmes. The longer-term impact, I think, is fascinating. To put it simply, Biafra generated a desire among humanitarian NGOs to replicate their interventions elsewhere. This contributed to what Mark Duffield later called the sense of 'permanent emergency' that helped sustain the humanitarian sector's presence in the Global South [Duffield, 2007]. It also helped to create an international community of aid workers, alongside new international networks of NGOs. The NGO sector's reputation was completely transformed by the crisis in the sense that the public came to see those organisations as the key link between them and the Third World. While I think that the phrase that NGOs like Oxfam and
Concern used to describe their activities - 'people to people action' - is problematic, it nonetheless provides us with a good insight into how people in the West viewed them.

Marie-Luce: And these questions also had a big impact on the established humanitarian organisations and on the attempts of coordination between them. The ICRC was quite shaken by its involvement in NigeriaBiafra, which proved that the organisation was not ready for this kind of crisis and needed to undertake a series of reforms (Desgrandchamps, 2012, 2014, 2018a, 2018b). It also impacted its reputation. As Florian Hannig has pointed out, when it came to coordinating international relief in East Pakistan and India, some countries preferred not to request ICRC's services on the basis of what had happened in Biafra (Hannig, 2018: 111-35).

Bertrand: I think this is very interesting. In my own research I have looked at later sites of epistemic communities or moments where humanitarians gathered. In Cambodia, for example, at the border of Thailand from 1979, about 10 years later, you don't find many people who claim to have been formed by the Nigeria experience in the field. You find them already quite high up in organisations (Taithe, 2016). So it's interesting that they do exist, but they are already, in the space of 10 years, regarded as old hands. Quite a few of them are in decisional roles or in major positions. For example the United Nations High Commissioner for Refugees from 1986 until 1989, Jean-Pierre Hocké, was an ex-ICRC director whose career started in Biafra. It seems quite interesting that we witness a fairly quick maturing of a proto humanitarian system in the 1970s.

Kevin: I agree, and this returns us to what I was talking about earlier in terms of describing the Biafran crisis as a moment of acceleration. Once these aid workers - many of whom had their first taste of emergency relief in Biafra - moved up the ranks in their organisations, they also began to re-shape the character of the sector. To come back to what you said, this is a period when things changed quite rapidly. In addition to the continuities from empire and Christian missionaries, the late 1960s was also a period when quite a number of individuals enter the sector from other backgrounds. This, in turn, expanded this pool of skills and knowledge, and made expertise more prominent in defining the purpose of NGOs.

Lasse: I would like to expand on the different ways the conflict continues after its end. In post-war Nigeria, the conflict continued to linger on and is still there, as the case of more recent incarnations of the vision of an independent Biafra show. Within the humanitarian sector, Biafra also continued for quite a while, probably for decades. In a way, it is still present within humanitarian organisations as a key episode within narratives of 
transformation and origin myths. But that is entirely different if we look at the larger public. For the larger public, I think the war was basically over before it ended. The coverage of the conflict was substantially diminished by the impact of the reports of the observer team. The publication of their reports was in some respects the first moment when the conflict ended. There were more substantial international reports again at the end of the conflict - its official end. However, afterwards, Biafra disappeared very quickly [Heerten, 2017: chapters 8-9]. This is also reflected in how historians, journalists and other writers have covered the 1960s: Biafra is not part of dominant narratives about the decade. The protagonists that turned Biafra into an event at the time were not part of the New Left; the global 1960s and the protests of the period are often memorised and re-narrated by exactly these protagonists of the contemporary New Left. In effect, protests that have not been part of the New Leftist universe are eclipsed and disappear. The iconography also factors into this process. After Biafra, similar images re-appeared again and again, with Live Aid and Band Aid, and after that Somalia and Sudan, and even more recently with what has become known as the 'refugee crisis' of 2015. The moment when the photograph of Alan Kurdi appeared in the media, this was in some respects reminiscent of Biafra [Fehrenbach and Rodogno, 2016]. But if you ask anyone outside Nigeria and outside of humanitarian organisations today, very few will know what Biafra was. Biafra helped establish a postcolonial iconography of human suffering but, because of humanitarianism's depoliticising effects, this exact optic also permitted the conflict itself to vanish from view.

Kevin: The word 'Biafra' nonetheless resonated for quite a long time, certainly in an Irish context, and for certain generations. That image endured, even if the details became less important as time went on.

Lasse: I would agree, in Germany, for instance, these stories also lingered on and were still present until the 1970s and 1980s. In the ensuing decades they widely disappeared and are barely present today.

Bertrand: Thank you very much. We are coming to the end now, so I'm going to ask a very basic, simple question. You have all written very important texts in relation to the Biafran war. You're all moving away a little bit from Biafra, and I'd like to ask you, are there any research questions that need further research now?

Lasse: One of the books that I am looking forward to in particular is Sam Daly's forthcoming monograph. It will not be about the humanitarian dimension of the conflict but - and I think this is a valid path for more research that still needs to be done - on Nigerian/Biafran society during the conflict [Daly, forthcoming; see also Daly, 2017, 2018a, 2018b). We still need to augment archival-based Africanist perspectives on the conflict, something that I felt was frustratingly lacking when I was writing my book. There are also still quite a few archives internationally which would be interesting to cover more deeply, for instance, Portuguese archives, as the research we have on the Portuguese case has barely made use of them.

Kevin: I would echo Lasse's point about recovering the recipient narrative - this is almost completely missing, and it would obviously be very, very useful to have a much better sense of what it was like to be on the receiving end of this aid. Related to this, I also think we need to do a lot more to recover the gender dynamics of the Biafran crisis. On the one hand, we know that this was quite a brutal conflict, in which violence against women was a prominent tactic. On the other, reading the crisis through a gender studies/gender history lens might also help to recover the role played by nuns, female nurses, women doctors and other aid workers in the crisis - we talk a lot about missionaries as men and aid workers as men, but women played a sizeable role in the delivery of aid.

Lasse: Just to echo that: I also only discovered glimpses into a more complex understanding of how gender worked in the field. Our narratives about humanitarian work are predominantly masculine narratives - echoing the way Biafra aid, for instance, was internationally narrated [Heerten, 2017: 158-67]. However, it is about time to arrive at a more nuanced picture.

Marie-Luce: I agree very much with all that. Another dimension that could be interesting to investigate further is the role of Nigerian relief organisations. As they were sitting at the crossroad between international networks and national imperatives, they acquired an important role in the coordination of the relief operations in the territories retaken by the Nigerian army during the last year of the conflict and its aftermath. More generally, I think it is interesting to look at these local organisations that are part of international networks, as they have been playing an increasingly important role within the humanitarian system.

Arua: There are some important aspects of the war that are still buried in the survivor-victims' minds. The gender dynamics, which Kevin and Lasse rightly pointed out, are yet to be fully explored. Stories of women who served as cooks for the Nigerian and Biafran soldiers as well as those who the Nigerian soldiers used as 'comfort women' in Biafra have not been adequately captured in the narrative. How about the women who engaged in cross-border trade (ahia attaakie)? Their risky efforts in bringing in food and other essentials from Nigeria complemented the efforts of the international humanitarian agencies. More importantly, we are yet to investigate the evacuation of the acutely malnourished Biafran 
children to neighbouring West African countries. The survivors of the evacuation and their parents still have their experiences to share. I think scholars can recover most of these aspects of the war through oral history.

\section{Bibliography}

Bangarth, S. (2016), 'The politics of African intervention: Canada and Biafra, 1967-70', in Carroll, M. K. and Donaghy, G. (eds), From Kinshasa to Kandahar: Canada and Fragile States in Historical Perspective (Calgary, AB: University of Calgary Press), pp. 53-72.

Barnett, M. (2011), Empire of Humanity: A History of Humanitarianism (Ithaca, NY: Cornell University Press).

Bateman, F. (2012), 'Ireland and the Nigeria-Biafra War: Local Connections to a Distant Conflict', New Hibernia Review, 16:1, 48-67.

Bocking-Welch, A. (2019), British Civic Society at the End of Empire: Decolonisation, Globalisation, and International Responsibility (Manchester: Manchester University Press).

Bredekamp, H. (2015), Der Bildakt: Frankfurter Adorno-Vorlesungen 2007 (Berlin: Klaus Wagenbach, 2nd edn).

Brink, C. (1998), Ikonen der Vernichtung. Öffentlicher Gebrauch von Fotografien aus nationalsozialistischen Konzentrationslagern nach 1945 (Berlin: Akademie Verlag).

Byrne, T. (1997), Airlift to Biafra: Breaching the Blockade (Dublin: The Columba Press).

Cesarani, D. and Sundquist, E. J. (eds) (2011), After the Holocaust: Challenging the Myth of Silence (London and New York: Routledge).

Chabbott, C. (1999), 'Development INGOs', in Boli, J. and Thomas, G. M. (eds), Constructing World Culture: International Nongovernmental Organisations since 1875 (Stanford, CA: Stanford University Press), pp. 222-48.

Cooper, F. (2008), 'Possibility and Constraint: African Independence in Historical Perspective', Journal of African History, 49:2, 167-96.

Cronje, S. (1972), The World and Nigeria: The Diplomatic History of the Biafran War, 1967-1970 (London: Sidgwick \& Jackson).

Daly, J. A. and Saville, A. G. (1971), 'The History of Joint Church Aid: Volume III' (unpublished manuscript, Spiritan Archives, Dublin, Biafra Papers).

Daly, S. F. C. (2017), 'The Survival Con: Fraud and Forgery in the Republic of Biafra, 1967-1970', Journal of African History, 58:1, $129-44$.

Daly, S. F. C. (2018a) 'The case against Victor Banjo: Legal process and the governance of Biafra', in Moses, A. D. and Heerten, L. (eds), Postcolonial Conflict and the Question of Genocide: The Nigeria-Biafra War (New York: Routledge), pp. 95-112.

Daly, S. F. C. (2018b), "Hell Was Let Loose on the Country": The Social History of Military Technology in the Republic of Biafra,' African Studies Review, 61:3, 99-118.

Daly, S. F. C. (forthcoming), A History of the Republic of Biafra: Law, Crime, and the Nigerian Civil War (Cambridge: Cambridge University Press).

Davey, E. (2015), Idealism beyond Borders: The French Revolutionary Left and the Rise of Humanitarianism (1954-1988) (Cambridge: Cambridge University Press).

de St. Jorre, J. (1972), The Nigerian Civil War (London: Hodder \& Stoughton).

Desgrandchamps, M-L. (2012), “'Organising the Unpredictable”: The Nigeria-Biafra War and Its Impact on the ICRC', International Review of the Red Cross, 94:888, 1409-32.

Desgrandchamps, M-L. (2014), “'Dealing with Genocide”: The ICRC and the UN during the Nigeria-Biafra war, 1967-70', Journal of Genocide Research, 16:2-3, 281-97.
Desgrandchamps, M-L. (2018a), L'humanitaire en guerre civile. La crise du Biafra (1967-1970) (Rennes: Presses universitaires de Rennes).

Desgrandchamps, M-L. (2018b), 'Du Congo au Biafra. Guerres civiles et actions humanitaires dans les relations internationales postcoloniales', Relations internationales, 176:4, 55-67.

Dimier, V. (2014), The Invention of a European Development Aid Bureaucracy: Recycling Empire (Basingstoke: Palgrave Macmillan).

Duffield, M. (2007), Development, Security and Unending War: Governing the World of Peoples (Cambridge: Polity).

Farmar, T. (2002), Believing in Action: Concern, the First Thirty Years, 1968-1998 (Dublin: A. \& A. Farmar).

Fehrenbach, H. and Rodogno, D. (2016), “A Horrific Photo of a Drowned Syrian Child": Humanitarian Photography and NGO Media Strategies in Historical Perspective', International Review of the Red Cross, 97:900, 1121-55.

Gould, M. (2013), The Biafran War: The Struggle for Modern Nigeria (London: I.B. Tauris).

Hannig, F. (2018), 'The power of the refugees: The 1971 East Pakistan Crisis and origins of the UN's engagement with humanitarian aid', in O'Malley, A. and Jackson, S. (eds), The Institution of International Order: From the League of Nations to the United Nations (Abingdon and New York: Routledge), pp. 111-35.

Heerten, L. (2015), “A” as in Auschwitz, "B" as in Biafra: The Nigerian Civil War, visual narratives of genocide, and the fragmented universalization of the Holocaust', in Fehrenbach, H. and Rodogno, D. (eds), Humanitarian Photography: A History (New York: Cambridge University Press), pp. 249-74.

Heerten, L. (2017), The Biafran War and Postcolonial Humanitarianism: Spectacles of Suffering (Cambridge: Cambridge University Press).

Heerten, L. and Moses, A. D. (2014), 'The Nigeria-Biafra War: Postcolonial Conflict and the Question of Genocide', Journal of Genocide Research, 16:2-3, 169-203.

Hilton, M., Crowson, N., Mouhot, J-F. and McKay, J. (2012), $A$ Historical Guide to NGOs in Britain: Charities, Civil Society and the Voluntary Sector since 1945 (Basingstoke: Palgrave Macmillan).

Kalter, C. (2016), The Discovery of the Third World: Decolonization and the Rise of the New Left in France, c.1950-1976 (Cambridge: Cambridge University Press).

Knoch, H. (2001), Die Tat als Bild: Fotografien des Holocaust in der deutschen Erinnerungskultur (Hamburg: Hamburger Edition).

Levey, Z. (2014), 'Israel, Nigeria and the Biafra Civil War, 1967-70', Journal of Genocide Research, 16:2-3, 263-80.

Loescher, G. (2001), The UNHCR and World Politics: A Perilous Path (Oxford: Oxford University Press).

Missionary Service Centre (1968), 'Irish Missionary Personnel in Developing Countries: Statistical Analysis March 1968', supplement to Catholic Missions, 133:2.

Moses, A. D. and Heerten, L. (eds) (2018), Postcolonial Conflict and the Question of Genocide: The Nigeria-Biafra War, 1967-1970 (Abingdon: Routledge).

Myers, T. (2014), 'Local Action and Global Imagining: Youth, International Development, and the Walkathon Phenomenon in Sixties' and Seventies' Canada', Diplomatic History, 38:2, 282-93.

Omaka, A. O. (2016), The Biafran Humanitarian Crisis, 1967-1970: International Human Rights and Joint Church Aid (Madison, MD: Fairleigh Dickinson University Press).

Omaka, A. O. (2019), 'Through the Imperial Lens: The Role of Portugal in the Nigeria-Biafra War', Journal of Global South Studies, 36:1, 186-209.

O'Sullivan, K. (2012), Ireland, Africa and the End of Empire: Small State Identity in the Cold War, 1955-75 (Manchester: Manchester University Press).

O'Sullivan, K. (2014), 'Humanitarian Encounters: Biafra, NGOs and Imaginings of the Third World in Britain and Ireland, 1967-70', Journal of Genocide Research, 16:2-3, 299-315. 
O'Sullivan, K., Hilton, M. and Fiori, J. (2016), 'Humanitarianisms in Context', European Review of History, 23:1-2, 1-15.

Siebert, G. (2018), 'São Tomé and the Biafran War (1967-1970)', The International Journal of African Historical Studies, 51:2, 263-92.

Sliwinski, S. (2011), Human Rights in Camera (Chicago: The University of Chicago Press).

Smillie, I. (1985), The Land of Lost Content: A History of CUSO (Toronto, ON: Deneau Publishers \& Co.).

Smith, K. E. (2014), 'The UK and "Genocide" in Biafra', Journal of Genocide Research, 16:2-3, 247-62.
Starowicz, M. and Oliver, R. (1970), 'The War that Stabbed Canada's Conscience', Toronto Daily Star, 14 January.

Staunton, E. (1999), 'The Case of Biafra: Ireland and the Nigerian Civil War', Irish Historical Studies, 31:124, 513-34.

Taithe, B. (2016), 'The Cradle of the New Humanitarian System? International Work and European Volunteers at the Cambodian Border Camps, 1979-1993', Contemporary European History, 25:2, 335-58.

Zelizer, B. (1998), Remembering to Forget: Holocaust Memory through the Camera's Eye (Chicago: University of Chicago Press). 